\title{
KOMODIFIKASI RITUAL DALAM PRAKTIK BRIDAL SHOWER DI YOGYAKARTA
}

\author{
Rebekka Rismayanti, Irene Santika Vidiadari \\ Prodi Ilmu Komunikasi \\ Universitas Atma Jaya Yogyakarta \\ J1 Babarsari 44 Yogyakarta 55281 \\ Email: rebekka.rismayanti@uajy.ac.id,irene.vidiadari@uajy.ac.id
}

\begin{abstract}
Abstrak
Bridal shower merupakan sebuah ritual yang saat ini menjadi tren di Yogyakarta. Penyelenggaraan acara ini tidak terlepas dari paket acara yang disediakan oleh penyedia jasa Event Organizer (EO) atau Party Planner (PP). Dengan kata lain, paket acara ini menjadi komoditas dari para EO. Artikel ini membahas mengenai komodifikasi ritual dalam praktik bridal shower di Yogyakarta. Penelitian ini merupakan penelitian kualitatif dan pengumpulan datanya menggunakan wawancara mendalam kepada tiga penyedia jasa EO yang menyediakan jasa paket acara bridal shower. Hasil penelitian menunjukkan bahwa komodifikasi ini dilakukan oleh para penyedia jasa EO dalam bentuk ragam harga yang mempengaruhi kelengkapan paket acara seperti dekorasi, makanan, videografer, fotografer dan pembawa acara. Dekorasi dan dokumentasi digunakan untuk mengakomodasi kebutuhan konsumen yang ingin eksis di media sosial, dan mengutamakan pengalaman bersenang-senang bersama teman-teman calon pengantin. Pada sisi harga paket, EO mengacu pada standar harga dari kota besar seperti Jakarta dan Surabaya. Upaya diversifikasi tema bridal shower dan promosi melalui media sosial juga dilakukan oleh para EO untuk memperluas pasarnya.
\end{abstract}

Kata Kunci: Bridal Shower, Komodifikasi Ritual, Promosi, Tren Ritual.

Gaya hidup dan pemenuhannya adalah sesuatu yang penting bagi masyarakat modern saat ini. Melalui gaya hidup, seseorang membangun makna atas dirinya sendiri dan kemudian membuat perbedaan dengan orang lain.
Pemenuhan gaya hidup kemudian berimplikasi pada identitas yang dibangun seseorang, baik identitas pribadi maupun identitas sosial. Melalui gaya hidup dan identitas, seseorang dapat menjadi "berbeda" atau bahkan 
dapat menyatu dengan lingkungan kemudian dinamakan proses sosialnya. Sayangnya, proses komodifikasi (Mosco, 2019).

pemenuhan gaya hidup ini akan membawa seseorang pada perilaku konsumtif. Di Indonesia misalnya, menurut Ibrahim dalam Chaney (2011,

h. 8), lahirnya masyarakat konsumtif ditandai dengan semakin banyaknya tempat perbelanjaan, industri kecantikan, kuliner, dan area lain yang dapat memenuhi gaya hidup masyarakat konsumtif.

Fenomena gaya hidup konsumtif ini kemudian dimanfaatkan menjadi komoditas karena terkait dengan upaya perputaran modal dalam sistem kapitalisme dan bertujuan untuk mengumpulkan kapital yang lebih besar. Setiap produk yang dicari untuk memenuhi kebutuhan gaya hidup memiliki nilai guna, sehingga dapat diubah menjadi komoditas yang bernilai tukar serta dikomersilkan demi mendapat keuntungan. Proses ini 
Shower ini awalnya berkembang di beberapa negara Barat dan merupakan perayaan memberikan bingkisan atau hadiah, seperti peralatan rumah tangga, bagi calon mempelai, sebagai simbol untuk membantu dan meringakan beban ketika memasuki biduk rumah tangga (Laili, 2018). Namun ketika masuk Indonesia, tren ini kemudian menjadi sebuah ritual dengan perayaan mewah. Praktik ritual sendiri menurut Bell dalam Humaeni (2015, h. 173) merupakan sebuah strategi budaya yang bersifat khusus, mengatur ragam tindakan dan kegiatan untuk membedakan antara yang dianggap suci dan yang dianggap biasa. Praktik ini dikatakan mewah ketika diadopsi di Indonesia karena pihak yang melakukan perayaan ini mengadakan pesta, menyewa Event Organizer (EO), menyewa hotel dan restoran, serta menggunakan aksesoris dan ornamen mewah seperti cupcakes, selempang, dan pernak pernik lainnya.
Pihak yang mengemas perayaan Bridal Shower juga tentu berkontribusi terkait tren dari Bridal Shower ini, termasuk Event Organizer (EO) yang menjadi pihak yang turut serta menciptakan perayaan mewah dari Bridal Shower. Salbiah (2018) juga menjelaskan bahwa tren Bridal Shower membuat EO semaijn tertarik dan berfokus pada pengembangan praktik Bridal Shower ini menjadi ritual dan budaya khusus di masyarakat Indonesia. Salah satu EO, menurut Salbiah (2018) bahkan berpendapat bahwa mereka berharap tren dari praktik ini terus berkembang sehingga EO semakin dibutuhkan untuk menjadi sarana konsumen membuat perayaan Bridal Shower menjadi penting, menarik., mewah, dan bahkan tidak terlupakan. Realitas ini yang menjadi dasar peneliti untuk membedah komodifikasi yang dilakukan EO dalam praktik ritual Bridal Shower. 
Penelitian dilakukan dengan EO yang ada di Yogyakarta. Sebagaimana kita ketahui, Yogyakarta dikenal sebagai daerah yang kental akan budayanya. Selain itu, bagi masyarakat Yogyakarta, sebenarnya terdapat ritual tersendiri bagi calon mempelai sebelum jenjang pernikahan, yang dinamakan midodaraeni. Maka penelitian ini akan membedah dan mengkritisi mengenai realitas Bridal Shower sebagai tren dan ritual modern di Yogyakarta dari sudut pandang EO.

Kajian mengenai komodifikasi merupakan bagian dari ekonomi politik komunikasi. Mosco (2009, h.128-129) mengemukakan bahwa komodifikasi merupakan sebuah proses perubahan nilai suatu produk dari yang sifatnya fungsional hingga dapat dipertukarkan dengan nilai tukar tertentu. Proses perubahan ini berkaitan erat dengan upaya perputaran modal dalam sistem kapitalisme dan bertujuan untuk mengumpulkan kapital yang lebih besar. Setiap benda yang memiliki nilai guna, memiliki kemungkinan yang sangat besar pula untuk diubah menjadi komoditas yang bernilai tukar. Lebih dari itu, benda tersebut dapat dikomersilkan demi mendapat keuntungan.

Pada bukunya, Mosco (2009,h. 128) menjelaskan sebuah konsep yang disebut komodifikasi. Konsep ini memiliki keterkaitan pula dengan komunikasi. Kaitan antara komunikasi dan komodifikasi terdapat dalam dua dimensi (Mosco, 2009, h. 130). Pertama, proses komunikasi dan teknologi memiliki kontribusi dalam proses umum komodifikasi dalam bidang ekonomi secara keseluruhan. Kedua, proses komodifikasi bekerja dalam sebuah lingkungan kerja sebagai proses komunikasi dan institusi secara menyeluruh, sehingga berbagai usaha perbaikan dan kontradiksi yang terjadi 
dalam proses komodifikasi akan mempengaruhi pula proses komunikasi sebagai sebuah praktik sosial.

Pada proses komodifikasi, media memiliki peran penting dalam pembuatan teks media: konsep,isu, ideologi, genre, proses produksi, jam tayang siaran, hingga tata letak halaman di media cetak. Selain itu, dalam proses komodifikasi pada media juga memilih simbol yang digunakan sebagai representasi sebuah kepentingan dari sisi ekonomi dan politik. Penggunaan simbol ini yang kemudian menjadikan teks media sebagai arena pertarungan makna yang menimbulkan praktik komodifikasi.

Ritual sendiri merupakan rangkaian perilaku yang mengkomunikasikan informasi melalui sistem tanda (Eller, 2007, dalam Humaeni, 2015, h. 173). Praktik ritual sendiri menurut Bell (1992, dalam Humaeni, 2015, h. 173) merupakan sebuah strategi budaya yang bersifat khusus, mengatur ragam tindakan dan kegiatan untuk membedakan antara yang dianggap suci dan yang dianggap biasa. Pada praktiknya, ritual melibatkan masyarakat dan pada praktiknya, ritual memiliki pemaknaan yang mendalam bagi kelompok masyarakat tersebut.

Di masa sekarang, pergeseran nilai dari ritual dan kepercayaan mengalami pergeseran ke nilai tukar. Proses komodifikasi nilai ritual dan kepercayaan ini salah satunya dilakukan oleh media massa. Proses pergeseran ini selaras dengan logika bisnis, bahwa budaya maupun agama mengandung daya tarik bagi konsumen media. Konsumsi yang dilakukan ini tidak berhenti pada persoalan menonton saja, lebih jauh lagi, para penonton ikut mempraktikkan nilai-nilai yang disampaikan melalui media. Syahputra (2016, h. 126) menyatakan bahwa dalam industri media massa seperti televisi, simbol yang merupakan cerminan agama 
hanya berhenti menjadi komoditas

religius melalui proses penyederhanaana

simbolik. Penyederhanaan simbolik

yang dilakukan pada agama di media

massa ini kemudian mendangkalkan

pemahaman atas agama itu sendiri, yang

membuat pemahaman agama hanya

terbatas pada simbol-simbol yang

tampak di luar dan bukan pada

pemaknaan yang mendalam.

Hermawan (2009, h. 41)

mengemukakan bahwa nilai agama

sudah dieksploitasi oleh perusahaan

media melalui beragam konten: sinetron

mistis, reality show, gelar wicara, dan

ragam konten lainnya. Melalui ragam

konten yang bermuatan nilai agama ini,

televisi mampu menarik pengiklan dan

memperoleh keuntungan. Proses

komodifikasi pada tayangan televisi ini

kemudian menjadikan agama sebagai

fetish dan kemudian menjadi acuan

hidup sehari-hari bagi penontonnya.

Lebih jauh lagi, komodifikasi tidak berhenti pada tontonan di media saja.

Tontonan media juga mempengaruhi pola konsumsi masyarakat. Hasil penelitian Lukmantoro (2004, h. 22) menunjukkan bahwa pola konsumsi masyarakat berubah pada saat menjelang hari raya. Harga bahan pokok mengalami kenaikan, ragam produk yang dijual menjelang hari raya keagamaan juga identik dengan simbolsimbil keagamaan. Pada tahap ini, agama menjadi kembali menjadi komoditas melalui barang-barang yang dijual di pusat perbelanjaan dan lekat dengan hari raya tersebut. Misalnya saja, penjualan pohon cemara dan pernak pernik natal di akhir tahun, penjualan baju panjang dan hijab menjelang hari raya Idul Fitri.

Selain agama, proses komodifikasi juga dilakukan pada ritual budaya lokal. Inisiator dari komodifikasi ini tidak semata media, namun juga pemerintah daerah yang memandang bahwa sebuah ritual budaya mampu meningkatkan 
pendapatan daerah. Yuliati (2016, h. 190)

pada penelitiannya di Bengkulu

mengemukakan bahwa Dinas Pariwisata

Propinsi Bengkulu melakukan

kerjasama dengan keluarga Kerukunan

Tabot untuk mengadakan sebuah festival

religi Tabot. Upacara Tabot yang

awalnya merupakan sebuah ritual untuk

menghormati cucu nabi Muhammad dan

hanya dirayakan oleh keluarga

keturunan Tabot, kini menjadi aset yang

dapat diakses masyarakat luas dan para

wisatawan. Tidak hanya di Bengkulu,

proses komodifikasi yang dilakukan oleh

pemerintah daerah melalui Dinas

Pariwisata juga terdapat di Jawa Barat

melalui upacara Seren Taun. Perubahan

nilai dari pemaknaan syukur atas hasil

panen berubah menjadi bernilai tukar

demi menarik wisatawan lokal maupun

dari luar Jawa Barat (Kompas, 2008).

Komodifikasi pada ritual ternyata tidak

hanya terjadi pada ritual-ritual yang

sifatnya keagamaan saja, tetapi juga terjadi pada ritual pop yang dikenal dengan bridal shower.

Penelitian terdahulu yang terkait dengan bridal shower dan pesta lajang sebelum pernikahan pernah dilakukan oleh Febriana dkk (2019) yang berjudul "Bridal Shower Phenomenon Among Women in Surakarta City (A Phenomenological Study on Consumptive Behavior due to Globalization Current)". Penelitian ini bertujuan untuk menjelaskan dimensi internal dan eksternal dari bridal shower serta menggambarkan perilaku konsumtif dari Bridal Shower. Hasil penelitian menunjukkan bahwa terdapat dimensi internal dan eksternal pada bridal shower. Selain itu, terkait perilaku konsumtif, bridal shower ternyata tidak hanya diadakan sederhana, tetapi para aktor juga mencoba membuat pesta ini semeriah dan semenarik mungkin. Mereka harus mengeluarkan banyak uang untuk mengadakan pesta bridal 
shower di kafe, restoran, maupun hotel.

Mereka juga harus menyewa Event

Organizer untuk mendekorasi ruangan pesta.

Penelitian kedua adalah milik Njonjo (2013) yang berjudul 'Socializing Women into Marital Responsibilities: $\quad$ The Emerging Phenomena of Bachelorrete Parties Among Educated Young Women in Nairobi'. Penelitian ini mendeskripsikan pergeseran nilai dan makna dari realitas pesta lajang di Kenya. Hasil penelitian menggambarkan bahwa praktik pesta lajang kemudian dianggap menjadi sarana sosialisasi mengenai peran lakilaki dan perempuan ketika memasuki biduk rumah tangga. Hal ini ditunjukkan dengan edukasi seputar seksualitas yang diperoleh calon pengantin dalam pesta ini. Dua penelitian sebelumnya terkait bridal shower lebih menekankan pada persoalan perilaku konsumtif dan persoalan nilai yang dibagikan dalam sebuah kelompok masyarakat. Persoalan perubahan nilai budaya dalam ritual bridal shower menjadi komoditas bagi pelaku bisnis belum dibahas dalam penelitian sebelumnya. Hal ini yang menjadi fokus pembahasan dalam artikel ini.

\section{Metodologi Penelitian}

Penelitian ini adalah penelitian kualitatif yang mengutamakan kedalaman analisis. Fokus penelitiannya adalah pada komodifikasi ritual baru yang menjadi tren di Yogyakarta, yakni bridal shower. Proses pengumpulan data dilakukan dengan wawancara pada tiga penyedia jasa Event Organizer (EO) atau Party Planner (PP) di Yogyakarta yakni DW dari Kunena, FB dari Adorable dan TK dari Kartanala. Wawancara dilakukan untuk mendapatkan data mengenai proses kreatif pembentukkan paket acara bridal shower, penentuan harga atas jasa 
penyelenggaraan acara, dan proses promosi. Penggalian data ini yang kemudian melihat bentuk-bentuk komodifikasi atas ritual bridal shower.

\section{Hasil dan Pembahasan}

\section{Bridal Shower: Tren Ritual dari Kota}

\section{Metropolitan}

Bridal shower yang merupakan ritual baru di Yogyakarta. Ritual, dalam prespektif perilaku konsumen, adalah momen sakral dalam kehidupan konsumen yang terpisah dari kebiasaan sehari-hari, di mana pembentukan nilai bukan hanya tindakan biasa, tetapi juga terkait dengan sebuah pengalaman. Tidak seperti sebuah kebiasaan, ritual dapat berlangsung lebih dari satu orang dan dalam jangka waktu yang lama (Servadio, 2018). di Yogyakarta, menurut FB sebagai informan penelitian, mengemukakan bahwa tren bridal shower dimulai sejak tahun 2015. Berkembangnya tren ritual ini dikarenakan praktik ritual ini sudah lebih dulu menjadi tren di kota-kota lain seperti Surabaya, Jakarta, dan Bandung. Berkembangnya kegiatan bridal shower dari satu kota ke kota lain menyebabkan Yogyakarta pun sebagai salah satu kota besar di Indonesia, sekaligus merupakan lokasi di mana banyak warganya berasal dari warga perantauan juga ikut dalam tren ini menjadi sebuah kebiasaan, bahkan bisa dikatakan menjadi ritual.

FB sendiri, awalnya merancang bridal shower karena ada seorang teman yang memintanya membuat sebuah paket acara untuk bridal shower. Pada proses penyusunan paket acara ini, FB mencari referensi dari party planner dari kota Surabaya dan Jakarta. Melalui pencarian ini, FB mengetahui bahwa di kota tersebut bridal shower sudah menjadi tren. Cheal (dalam Servadio, 2018) mengklaim bahwa dalam sebuah ritual, makna ritual berorientasi pada tujuan terkait nilai-nilai yang dimiliki 
oleh semua anggota masyarakat tertentu.

Berkaitan dengan penelitian ini, Adopsi

terkait tren bridal shower dilihat sebagai

nilai yang secara makro dimaknai

bersama mengenai bridal shower sebagai

suatu tren yang menarik dan

menguntungkan sehingga kemudian

party planner di Jogja sepakat terhadap

nilai yang sama sehingga tidak dimaknai

secara terpisah, namun sebagai tren

bersama, meskipun pelaksanaannya

dilakukan di daerah-daerah yang

berbeda.

Bridal shower sebagai sebuah tren kini menjadi sebuah ritual baru di kalangan anak muda di Yogyakarta.

Bridal shower dianggap sebagai representasi gaya hidup masyarakat modern, diadopsi oleh beberapa kota besar di Indonesia, serta memberikan simbol-simbol tertentu oleh para penggunanya. Nilai-nilai yang diusung dalam bridal shower merujuk pada nilai persahabatan dan hiburan. Hal ini yang membuat rancangan paket acara bridal shower dibuat sangat santai dan menghibur dengan berbagai permainan yang disediakan penyedia jasa. Pada sisi yang lain, dari persoalan estetika, seringkali perayaan bridal shower mengusung tema-tema yang unik, sesuai permintaan konsumen.

"Kalau ada klien yang nanyain tema biasanya bridal shower lebih ke Maurine Monroe, Betty Boop, yang cewek genit Victoria Secret" (FB, penyedia jasa EO Adorable, wawancara 6 Januari 2020).

Pilihan tema dan dekorasi yang digunakan selama acara berlangsung menjadi hal yang penting karena dekorasi yang menarik dan aksesoris yang digunakan dapat memuaskan kebutuhan eksistensi konsumen di ranah media sosial. Hal ini dikemukakan oleh DW, penyedia jasa EO dari Kunena

"Kadang, ketika kami menghidangkan makanan, para undangan bridal shower seolah-olah tidak peduli. Mereka sibuk berfoto dan mengunggah ke media sosial. Dari sini kelihatan bahwa dekorasi merupakan hal yang penting dalam bridal shower karena mereka lebih 
membutuhkan hal itu untuk media sosialnya" (DW, wawancara 6 Januari 2020).

Kebutuhan untuk bersenang-senang di sela-sela mempersiapkan pernikahan mengakibatkan Bridal Shower menjadi suatu ritual baru bagi masyarakat modern sebelum memasuki jenjang pernikahan. Di sini lain, Party Planner merupakan pihak yang kemudian menjadi jembatan adopsi tren tersebut melalui simbol-simbol dan berbagai elemen yang ditawarkan dalam paketpaket acara serta kreativitas yang terkandung di dalamnya. FB mengemukakan bahwa dalam mengelola acara bridal shower untuk klien, FB melihat bahwa bridal shower tidak hanya menjadi ajang berkumpul para sahabat dan berbagi nostalgia sebelum calon pengantin memasuki jenjang pernikahan, tetapi juga "diatur" dengan adanya susunan acara dan MC. Dalam membuat susunan acara, FB biasanya membuat susunan acara yang cenderung mirip, meskipun permintaan beragam dari klien, yakni:

\section{Pembukaan}

2. Opening speech oleh calon pengantin

\section{Games}

4. Testimony dari para sahabat calon pengantin

5. Mencoret-coret muka calon pengantin

6. Foto-foto

7. Membagi bingkisan

\section{Makan bersama}

Melalui susunan acara ini terlihat bahwa implementasi bridal shower dapat dilihat sebagai bentuk tren yang mengarah pada ritual yang positif, di mana ritual positif lebih mengarahkan pada perayaan yang bertujuan untuk memperoleh kebahagiaan. Maka nilainilai yang dipercaya pun positif mengikuti tujuan ritual itu dilakukan. 
Hal ini juga terkait dengan pernyataan menurut Driver (dalam Servadio, 2018) yang menyebutkan bahwa karakateristik ritual, tidak hanya dilihat dalam konteks positif maupun negatif, tetapi lebih dalam lagi. Ritual mampu menyatukan orang karena ritual cenderung mengikat orang secara emosional dengan adanya rasa kebersamaan. Pada konteks ini, bridal shower yang awalnya merupakan tren yang berkembang di luar negeri, hingga kemudian menjadi tren, bahkan ritual penting sebelum menikah bagi perempuan muda di Yogyakarta dilihat sebagai sebuah simbol yang bertingkat. Bridal shower tidak hanya terkait dengan momen sebelum menikah, namun nostalgia antar teman dan mempererat persahabatan di antara orang-ornag yang terlibat di dalamnya. Lanjutan dari karakteristik ini, setiap pihak memainkan perannya dalam menyukseskan implementasi bridal shower, termasuk Party planner berperan sebagai pihak ketiga yang bertugas untuk membuat acara bridal shower memnjadi semenarik mungkin bagi para kliennya.

FB juga mengemukakan bahwa selama hampir 5 tahun ia mengelola party planner, terjadi perubahanperubahan permintaan dari klien bridal shower. Awalnya klien hanya meminta jasa dekorasi, lalu seiring berjalannya waktu, kliennya semakin ingin sesuatu yang praktis. Meminta paket acara bridal shower lengkap dengan MC dan tim dokumentasi. Biaya yang dikeluarkan oleh klien juga tidak sedikit. Paket acara bridal shower dengan 6 orang tamu undangan, klien harus menyiapkan budget sekitar 3juta rupiah. FB mengemukakan pula bahwa ia pernah mendapat klien yang mengundang 25 orang dan harus menyiapkan budget sekitar 6juta rupiah. Pada penyelenggaraan bridal shower yang tidak jarang menggunakan MC (master of ceremony), 
Hal yang sama juga dikemukakan oleh TK dari Kartanala, ia menyebutkan bahwa tahun 2015, saat party planner yang ia dirikan bersama teman-teman kuliahnya baru berdiri, ia mendapat klien yang ingin mengadakan bridal shower dan memintanya untuk membuat paket harga dekorasi untuk bridal shower. Hal ini tentu ia sanggupi dan ia mulai mencari referensi di internet tentang dekorasi tempat untuk bridal shower. Berangkat dari pengalaman ini, ia mulai melakukan riset pasar dan membuat paket harga dekorasi bridal shower dan biaya dokumentasi acara tersebut untuk menarik kliennya. TK mengemukakan bahwa untuk paket acara bridal shower yang ia sediakan, ia menyiapkan dekorasi, dokumentasi dan cake. Di party plannernya terdapat 3 paket harga: 4,4juta rupiah, 3,5juta rupiah, dan 1,5 juta rupiah.

Penentuan paket acara dan harga yang disusun oleh narasumber penelitian menunjukkan bahwa Bridal Shower yang dilihat sebagai sebuah ritual baru memunculkan berbagai elemen yang menyusunnya, seperti yang juga disampaikan Rook (1985) ketika berbicara mengenai fitur-fitur dan elemen pembentuk ritual. Daftar harga paket masuk pada konteks pada sisi artefak dalam Ritual. Daftar paket harga menunjukkan kemampuan dan fasilitas yang dapat diperoleh oleh klien ketika menggunakan jasa party planner untuk acara Bridal Shower. Perbedaan harga paket menentukan artefak-artefak lain yang diberikan party planner utk klien, seperti dekorasi, makanan, lokasi, dan kreativitas acara. Pada akhirnya, artefak pada bridal shower juga menunjukkan tingkat kemampuan membayar dari para klien. Semakin mahal paket yang dipilih, maka akan semakin kreatif atau mewah acara yang akan disusun. Dekorasi, variasi makanan dan pemilihan lokasi pun menjadi berbeda. Narasumber 
menyebutkan bahwa pentingnya mempererat persahabatan ditunjukkan

membagikan pengalaman acara bridal shower di media sosial juga menunjukkan tidak hanya kemampuan klien dalam mengadakan acara bridal shower yang menarik, tetapi juga kelas dan status sosial yang dimiliki konsumen ketika mengadakan acara bridal shower yang meriah dan dihadiri oleh banyak teman.

Di sisi lain, dalam konteks elemen ritual yang lain, yakni script, acara yang dibuat dan narasi yang disusun oleh party planner melalui acara tersebut menunjukkan nilai-nilai yang ingin dimiliki dan dipererat melalui acara bridal shower tersebut. Meskipun paket harga yang ditawarkan bisa saja berbedabeda, namun nilai yang ingin diusung melalui susunan acara cenderung mirip. Seperti sudah dijelaskan di karakteristik ritual, bridal shower yang diharapkan dapat menjadi sarana nostalgia antar teman dan menjadi ajang untuk dengan susunan acara di mana selalu ada terselip mata acara testimoni atau foto bersama antara calon pengantin dan teman-teman yang hadir dalam acara bridal shower. Artinya, perbedaan harga kemudian tidak semata-mata membuat juga perbedaan dengan nilai utama bridal shower ingin dikembangkan dan ditunjukkan melalui rundown acara yang dibuat oleh para party planner. Semua pihak yang hadir di situ, baik calon pengantin maupun teman-teman, yang dalam elemen ritual disebut sebagai ritual audience, mencoba menyepakati makna bridal shower tidak hanya sebagai ritual modern sebelum memasuki jenjang pernikahan, tetapi juga ajang bertemu dan bernostalgia dengan temanteman, meskipun disusun dengan paket harga yang berbeda-beda dan dekorasi yang bermacam-macam.

\section{Komodifikasi Ritual dalam Praktik}

Bridal Shower 
Mosco (2009, h.128-129) mengemukakan bahwa komodifikasi merupakan sebuah proses perubahan nilai suatu produk dari yang sifatnya fungsional hingga dapat dipertukarkan dengan nilai tukar tertentu. Proses perubahan ini berkaitan erat dengan upaya perputaran modal dalam sistem kapitalisme dan bertujuan untuk mengumpulkan kapital yang lebih besar. Hal ini dikemukakan oleh para party planner bahwa bridal shower merupakan salah satu upaya untuk memutar modal yang mereka miliki, di samping produk lain yang mereka tawarkan seperti acara ulang tahun anak-anak, perayaan ulang tahun pernikahan, lamaran, maupun acara pernikahan. Menurut FB dan DW, menyediakan jasa bridal shower cukup potensial dan menjanjikan, terutama karena mereka dapat memanfaatkan berbagai peralatan dekorasi yang sudah dimiliki secara berulang-ulang. Mereka hanya perlu lebih kreatif ketika membuat dekorasi dari barang-barang yang sudah ada.

$$
\text { Perputaran modal melalui }
$$
penyelenggaraan bridal shower ini ditentukan pula dari penentuan harga paket yang disediakan. Perbedaan harga paket yang dimiliki oleh party planner dalam mengadakan acara bridal shower dibuat berdasarkan standar harga paket yang dimiliki party planner sejenis di Jakarta. Padahal jika dilihat, standar kemampuan dan pendapatan perkapita antara Jakarta sebagai Ibukota negara dan Yogyakarta sebagai Daerah Istimewa sangat berbeda. Harga ini diadopsi untuk memberikan standar di Yogyakarta untuk mengadakan acara Bridal Shower. Proses adopsi ini akhrinya menimbulkan elemen-elemen yang terkandung dalam harga paket tersebut juga disesuaikan sehingga semakin mahal harga paket yang ditawarkan, makan semakin variatif dan kreatif acara yang dapat diadakan. 
Perbedaan harga terletak pada perbedaa fasilitas dan elemen yang diperoleh klien untuk acara bridal shower yang ingin diadakan, seperti pemilihan lokasi, pemilihan makanan, dekorasi bunga, hiasan meja, properti foto, serta konsep acara yang diusung. Selain itu, perbedaan hasil dokumentasi yang diperoleh juga menentukan perbedaan harga paket dibuat, seperti jumlah foto, adanya video dengan shotshot yang menarik, maupun foto dan video yang dapat diperoleh keduanya oleh klien. Semakin mahal paket yang diambil, maka semakin variatif pula hasil dokumentasi yang diperoleh klien. Nantinya, perbedaan properti dan hasil dokumentasi yang ditunjukkan melalui harga paket yang berbeda dapat terlihat di media sosial klien. Kebutuhan untuk menunjukkan hal tersebut di media sosial menjadi nilai yang kemudian tidak lagi bicara mengenai nilai persahabatan, tapi status dan kemampuan seseorang dalam membuat acara bridal shower dengan jumlah teman yang banyak dan acara yang meriah. Kemewahan dan kemeriahan acara bridal shower yang diadakan menjadi peluang yang dimanfaatkan party palnner untuk membedakan harga paket secara signifikan.

Pada sisi yang berbeda, komunikasi dan komodifikasi juga memiliki kaitan yang terdapat dalam dua dimensi (Mosco, 2009, h. 130): Pertama, proses komunikasi dan teknologi memiliki kontribusi dalam proses umum komodifikasi dalam bidang ekonomi secara keseluruhan. Kedua, proses komodifikasi bekerja dalam sebuah lingkungan kerja sebagai proses komunikasi dan institusi secara menyeluruh, sehingga berbagai usaha perbaikan dan kontradiksi yang terjadi dalam proses komodifikasi akan mempengaruhi pula proses komunikasi sebagai sebuah praktik sosial. Hal ini 
dapat dilihat dari cara para event organizer atau party planner mereproduksi pesan tentang bridal shower melalui foto yang mereka unggah di media sosial. Ragam tema yang dipilih oleh konsumen membawa keuntungan tersendiri bagi para EO. Mereka bisa menunjukkan beragam kreasi tema dan aksesoris yang dapat mereka sediakan untuk konsumennya sekaligus menjadi portofolio bagi party planner. Selain itu, konsumen secara sukarela juga mengunggah foto dan video, memberikan tautana nama penyelenggara acara dalam unggahan untuk menunjukkan siapa EO yang menyelenggarakan acara. Bagi EO sendiri, ini merupakan promosi gratis.

$$
\text { Mosco (2009, h. 130) }
$$
mengemukakan bahwa pada proses komodifikasi, media memiliki peran penting dalam pembuatan teks media. Selain itu, dalam proses komodifikasi pada media juga memilih simbol yang digunakan sebagai representasi sebuah kepentingan dari sisi ekonomi dan politik. Penggunaan simbol ini yang kemudian menjadikan teks media sebagai arena pertarungan makna yang menimbulkan praktik komodifikasi. Hal ini juga terjadi pada proses komodifikasi dari ritual bridal shower. Perkembangan bridal shower di Indonesia tidak bisa lepas dari peran media sosial, khususnya instagram. Hal ini diakui oleh FB, DW dan TK. Mereka mengemukakan bahwa promosi yang mereka lakukan untuk memperkenalkan dan mempromosikan jasa party planner untuk bridal shower sangat efektif dilakukan melalui instagram, terlebih jika menggunakan tanda pagar (\#). Klien dapat dengan mudah menyaring informasi dan mendapatkan kontak party plannernya melalui pencarian dengan menggunakan hashtag.

Komodifikasi, dalam kerangka ekonomi politik komunikasi, ternyata 
tidak hanya muncul pada bentuk-bentuk

teks media, tetapi juga dalam bentuk

ritual yang diberi nilai lebih dengan

mempertimbangkan kebutuhan

eksistensi konsumen di media sosial.

Pelaku penyedia jasa EO dan party

planner memanfaatkan kebutuhan

tersebut dengan memanfaatkan peralatan

dekorasi yang mereka miliki, berkreasi

dan mencari referensi dari media yang

setelahnya mereka reproduksi dalam

bentuk paket acara bridal shower.

\section{Kesimpulan}

Praktik bridal shower di Yogyakarta tidak berhenti pada praktik ritual yang mengusung nilai-nilai persahabatan dan hiburan semata. Praktik ritual yang diadopsi dari negara lain, dipraktikkan di Yogyakarta dengan cara yang berbeda: menggunakan beragam permainan, dekorasi menarik, dan jasa fotografer, videografer serta pembawa acara. Kebutuhan akan meriahnya acara dan menariknya foto-foto yang akan diunggah di media sosial menjadi lahan bagi para event organizer untuk menjadikan ritual ini sebagai sebuah komoditas dari usaha yang mereka jalankan. Ragam tema dan paket acara jelas mempengaruhi harga yang ditawarkan. Selain itu, promosi gratis melalui unggahan media sosial dari konsumen mendukung keberlangsungan usaha party planeer dan reproduksi praktik ritual bridal shower.

\section{Daftar Pustaka}

Chaney, D. (2011). Lifestyles: Sebuah Pengantar Komprehensif. Yogyakarta: Jalasutra.

Febriana, Merri., Zuber, Ahmad., Haryono, Bagus. (2019). Bridal Shower Phenomenon Among Women in Surakarta City (A Phenomenological Study on Consumptibe Behavior due to Globalization Current). International Journal of Education and Social Science Research, 2 (03), h. 25-30. 
Hermawan, A. (2009). Spiritualisme Televisi: Antara Aqidah dan Komodifikasi. Jurnal Dakwah, $X(1)$. h. 33-52.

Humaeni, A. (2015). Ritual, Kepercayaan Lokal dan Identitas Budaya Masyarakat Ciomas Banten. El Harakah 17(2), h. 157-181.

Kompas. (2008). Seren Taun, Rasa Syukur yang Jadi Komoditas Wisata. Diakses pada 10 September 2019 dari https://travel.kompas.com/read/2008/12/22/10020260 /seren.taun.rasa.syukur.yang.jadi.komoditas. wisata?page $=1$

Laili, A. (2018). Ketika Perayaan bridal shower Menjadi Berbeda dari yang Semestinya. Diakses pada 2 April 2019 dari https://mojok.co/auk/ulasan/pojokan/ketika-perayaan-bridal-shower-menjadiberbeda-dari-yang-semestinya/

Lukmantoro, T. (2004). Ritual Hari Raya Agama: Histeria Konsumsi Massa dan Khotbah Industri Budaya. Jurnal Ilmu Komunikasi, 1(1), 19-36.

Mosco, Vincent. (2009). The Political Economy of Communication, edisi ke-2. London $\&$ New York: Sage.

Njojo, N. (2013). Socializing Women into Marital Responsibilities: The Emerging Phenomena of Bachelorrete Parties Among Educated Young Women in Nairobi. University of Nairobi: Faculty of Arts.

Rook, D.W. (1985). The Ritual Dimension of Consumer Behaviour. Journal of Consumer Research. 12 (3). 251-264.

Salbiah, Nurul Adriyana. (2018). Tren di Kalangan Milenial Ciptakan Kado Manis dengan Bridal shower. Jawapos.com. Diperoleh dari https://www.jawapos.com/lifestyle/26/08/2018/tren-di-kalangan-milenialciptakan-kado-manis-dengan-bridal-shower/

Servadio, L. (2018). Consumer Rituals:Etnographic Explorations of Wine Rituals with Families and Friends. Stockholm: Stockholm University.

Syahputra, I. (2016). Agama di Era Media: Kode Religius dalam Industri Televisi Indonesia. Esensia, 17(1), 125-138.

Yuliati. (2016). Upacara Religi dan Pemasaran Pariwisata di Provinsi Bengkulu. Jurnal Ilmu Sosial dan Ilmu Politik, 5(3), 185-194. 